\title{
Learnability problems in the acquisition of the manner-of- motion verbs in L2 English by L1 Spanish speakers
}

Problemas de aprendizaje de los verbos de movimiento en el idioma inglés por hablantes nativos del idioma español

Dificuldades de aprendizagem de verbos de movimento na língua inglesa por falantes nativos de espanhol

Salvador Bautista Maldonado

Universidad Autónoma del Carmen, México

sbautista@pampano.unacar.mx https://orcid.org/0000-0001-9816-1299

Gina del Pilar Pacheco Balam

Universidad Autónoma del Carmen, México

gpacheco@delfin.unacar.mx https://orcid.org/0000-0001-5852-0488

Rafael Ferrer Méndez

Universidad Autónoma del Carmen, México rferrer@pampano.unacar.mx https://orcid.org/0000-0003-3157-2311 


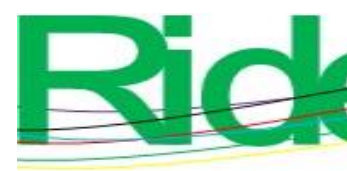

Revista Iberoamericana para la Investigación y el Desarrollo Educativo ISSN 2007-7467

\section{Resumen}

En inglés la oración "John ran into the house" tiene un significado semántico de dirección mientras que la misma oración, en español, tiene un significado semántico de ubicación. La diferencia reside en que, en el idioma inglés, los verbos conocidos como verbos de movimiento que al combinarse con una preposición de dirección resultan en una oración de dirección; mientras que en español solo existe un significado de ubicación y para expresar un evento con significado de dirección se requiere utilizar una oración diferente, como por ejemplo, "John entered the house running". Esta diferencia sintáctica-semántica causa problemas de aprendizaje del inglés a algunos hablantes. Algunas investigaciones previas revelan que los idiomas similares en este aspecto al español, como el japonés, presentan la misma problemática al transferir la gramática de la L1 a la L2 (Inagaki, 2002). Otro ejemplo es el del coreano, que al igual que el japonés y el español, presenta esta problemática de aprendizaje en el campo sintáctico-semántico inglés como L2 (Zubizarreta y Oh, 2007). Los lingüistas están de acuerdo en que esta problemática se puede analizar en como las lenguas expresan los eventos en los predicados complejos. Una de las teorías más utilizadas para el análisis de este tipo de eventos es la clasificación tipológica de las lenguas en Verb-Framed y Satellite-Framed (Talmy, 2000). Con el objetivo de investigar si los hispano hablantes adquieren el significado semántico-sintáctico de dirección, al combinar un verbo de movimiento con una preposición de dirección, en el idioma inglés, se realizo el siguiente experimento. Primeramente, se asumió que los hispanohablantes con un nivel bajo del idioma inglés iban a transferir las propiedades semánticas de su L1 expresar dirección en inglés y, que posteriormente, una vez que hubieran alcanzado un nivel mayor serían capaces de interiorizar la construcción correcta para expresar dirección en la L2. En esta investigación se aplicó un instrumento propuesto por Stringer (2012) que consiste en un set de dibujos en el que los participantes tenían que seleccionar la oración acorde al dibujo presentado. El instrumento se aplicó a 62 participantes que estaban divididos en tres grupos de estudio dependiendo de su nivel de inglés. Los grupos se conformaron de la siguiente manera: 27 participantes de nivel básico, 15 participantes de nivel intermedio y 20 participantes de nivel avanzado. Los resultados obtenidos muestran que incluso los participantes del nivel básico eran capaces de detectar correctamente las oraciones con un significado semántico de dirección. Al parecer, los resultados indican que los participantes en este experimento 


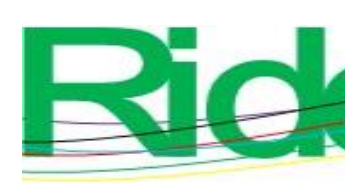

Revista Iberoamericana para la Investigación y el Desarrollo Educativo ISSN $2007-7467$

adquieren el significado semántico-sintáctico debido al aprendizaje que obtienen en el salón de clases, y esto les permite adquirir los verbos de movimiento desde niveles básicos.

Palabras clave: interface sintáctica-semántica, transferencia de la L1, intralenguaje, combinación, opcionalidad.

\section{Resumo}

Em inglês, a frase "John correu para a casa" tem um significado semântico de endereço, enquanto a mesma frase, em espanhol, tem um significado semântico de localização. A diferença é que, na língua inglesa, os verbos conhecidos como verbos de movimento que quando combinados com uma preposição de endereço resultam em uma frase de endereço; enquanto em espanhol há apenas um significado de local e para expressar um evento com um significado de direção é necessário usar uma frase diferente, como "João entrou na casa correndo". Essa diferença sintático-semântica causa problemas de aprendizagem de inglês para alguns falantes. Algumas pesquisas anteriores revelam que línguas semelhantes neste aspecto ao espanhol, como o japonês, apresentam o mesmo problema ao transferir a gramática de L1 para L2 (Inagaki, 2002). Outro exemplo é o coreano, que, assim como o japonês e o espanhol, apresenta esse problema de aprendizagem no campo sintáticosemântico do inglês como L2 (Zubizarreta e Oh, 2007). Os lingüistas concordam que esse problema pode ser analisado em como as línguas expressam eventos em predicados complexos. Uma das teorias mais utilizadas para a análise deste tipo de evento é a classificação tipológica das linguagens em Verb-Framed e Satellite-Framed (Talmy, 2000). Com o objetivo de investigar se os falantes do espanhol adquirem o sentido semânticosintático de direção, por meio da combinação de um verbo de movimento com uma preposição de direção, na língua inglesa, foi realizado o seguinte experimento. Em primeiro lugar, supôs-se que falantes de espanhol com baixo nível de inglês transfeririam as propriedades semânticas de seu L1 para expressar direção em inglês e, posteriormente, uma vez que atingissem um nível superior, seriam capazes de internalizar a construção correta para expressar direção. em L2. Nesta pesquisa, foi aplicado um instrumento proposto por Stringer (2012) que consiste em um conjunto de desenhos em que os participantes deveriam selecionar a frase de acordo com o desenho apresentado. O instrumento foi aplicado a 62 participantes, que foram divididos em três grupos de estudo, dependendo do nível de inglês. 


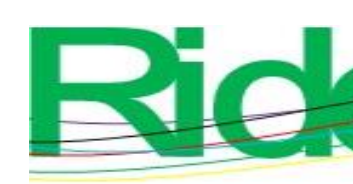

Revista Iberoamericana para la
Investigación y el Desarrollo Educativo
ISSN $2007-7467$

Os grupos foram formados da seguinte forma: 27 participantes de nível básico, 15 participantes de nível intermediário e 20 participantes de nível avançado. Os resultados obtidos mostram que mesmo os participantes do nível básico foram capazes de detectar corretamente sentenças com um significado semântico de direção. Aparentemente, os resultados indicam que os participantes desse experimento adquirem o significado semântico-sintático devido ao aprendizado que obtêm em sala de aula, e isso lhes permite adquirir os verbos de movimento dos níveis básicos.

Palavras-chave: interface sintático-semântica, transferência L1, intra-linguagem, combinação, opcionalidade.

Fecha Recepción: Noviembre 2019

Fecha Aceptación: Enero 2021

\section{Introduction}

The behavior of manner-of-motion-verbs have been studied by several linguists (Folli and Ramchand 2005, Mateu and Rigau 2002, Mateu 2002, among others). Previous studies reported show that it is required "positive" and "robust" input in order to map those conflation patterns in L2 English due to their semantic behavior of the verbs (Inagaki, 2001, 2002). Inagaki studies have been following the same line of inquiry as they follow the well-known typology distinction proposed by Talmy $(1985,1991,2000)$ the "satellite framed" languages (Germanic type languages) and the "Verb Framed" languages (mainly Romance type languages). The main claim of Inagaki (2002) relies on a relationship that he called Subsetsuperset between spatial prepositions. In other words, the Japanese language lacks spatial prepositions so Japanese learners of English need to go from a subset (Japanese) to a superset (English). After tested the subset-superset situation Inagaki concluded that Japanese speakers were not able to identify that English spatial prepositions have a directional component of meaning and he suggested that restructuring requires not only positive input but also 'robust' evidence from the target language input. Following the same topic (Inagaki 2001) conducted a bidirectional study testing Japanese learners of English and English learners of Japanese. Inagaki concluded that L1 speakers of Japanese could learn argument structure realization types not present in their L1. This is because there is available and positive input in the target language; but the English learners of Japanese failed to identify the argument structure realization pattern that is ungrammatical in Japanese. This suggests that the absence of evidence in the input persists when an argument structure realization pattern in the L2 


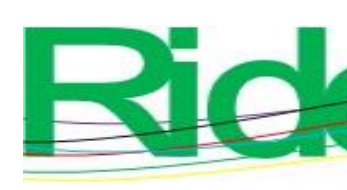

Revista Iberoamericana para la
Investigación y el Desarrollo Educativo
ISSN $2007-7467$

constitutes a subset of its counterpart in the L1. His results also suggest that the L2 acquisition of argument structure will not be difficult when the L2 is a superset of the L1 due to the availability of positive evidence, but transfer will be persistent when the L2 is a subset of the L1 (Inagaki 2001: 165). Hawkins (2019) reported another study of the acquisition of mannerof-motion verbs in L2 English. In this report, Hawkins reviews a study carried out by Bautista-Maldonado (2011) where Spanish speakers were tested using a Picture task with manner-of-motion events with sentences like the football rolled into the goal vs the football rolled in the goal, and the Spanish counterpart, the ball entered the goal rolling. In all constructions there were arrows showing the ball going from outside the goal and in the other the ball rolling inside the goal. The participants task, in this case three groups of L1 Spanish with different proficiency levels of English were tested, was to rate the naturalness of the sentences in a scale from +2 (very natural) to -2 (very unnatural). The results reported show that the low-proficiency speakers tend to use the Spanish pattern (the ball entered the goal rolling) to express motion, the lower-intermediate group and the advanced group tend to use the English pattern to express directionality, but still the advanced group showed some uses of the Spanish pattern. Another study is presented by Souza (2012) who investigated the manner of motion verbs by Brazilian students learning English as a foreign language. He tested Brazilian bilinguals and monolingual students. Souza tested how do the bilinguals and monolinguals learn the passivization and double-object transitives. Using a lexical decision task (eye-tracking experiment) he found that the lexical decision time task was more effective in their L1 than in their L2 of the bilingual. He concluded that there was L2 learnability problems when making the passivization of the manner of motion verbs.

Summing up, in this last study the input and the use of the English pattern does not pre-empt the Spanish version. The research presented here follows the same line of inquiry, in other words, the objective of this research is to see to what extent do Spanish speakers accept the directionality of the manner-of motion verbs, and to see if they are using constructions in their L1 in order to have an equivalent in the L2 ( Transfer) of the locative expressions of events and the directionality expression of events. Following this line of inquiry, and to provide an answer to the following research questions: Do Spanish speakers initially assume that the realization of directed manner of motion constructions in English is the same as in Spanish? And to what extent, the proficiency level of English is playing a role?. The next section reviews the theoretical framework used in this research, next the 


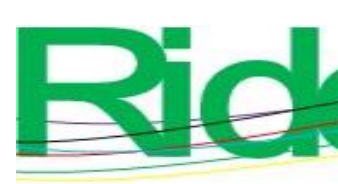

Revista Iberoamericana para la
Investigación y el Desarrollo Educativo
ISSN $2007-7467$

Rolled expresses Motion while blew represent Cause, then a verb can express Motion and Cause respectively.

Apart from these semantic features encoded in the events, Talmy $(1985,1991,2000)$ proposed three conflation types where the Motion, Path, a Co-event (manner or cause) or Figure can be lexicalized together in the verb. These conflation patterns have been the main source of discussion to express motion events in many languages, but still accepted as a basis for research when reporting lexical meaning of verbs and their participants. The three conflation patterns are explained below:

MOTION + Manner: In this conflation pattern, the verb expresses at once both the fact of motion and the manner of the motion. Most Indo-European families of languages seem to be of this type (except Romance languages). English is a good example of this conflation pattern:

The rock rolled down the hill (MANNER)

MOTION + Path: In this second type, the verb root at once expresses both the fact of motion and the path. If a Co-event of manner or cause is expressed in the same sentence, it must be as an independent adverbial or gerundive. The Spanish language is the best example of this type of conflation:

\section{La botella entró a la cueva (flotando)}

"The bottle entered in the cave (floating)" (in English: The bottle floated into the cave)

MOTION + Figure: In this last typology of conflation pattern, the verb expresses the fact of motion together with the figure. In English, this type of conflation is very rare but in an American native language such as Atsugewi this pattern is common:

Guts are lying on the ground (running of icky material)

With the meaning that they are moving and they are reaching the ground at the same time.

Apart from this typology, of the three conflation patterns, Talmy also classified languages into two main types depending on how those languages express the event of motion. Therefore, for Talmy there are two main types of languages: Satellite-Framed languages and Verb-Framed languages. A satellite-framed language is one that needs an exterior syntactic element to accompany the verb in order to express a motion path; in this case, the preposition is acting as a "satellite" of the verb (the rock rolled down the hill). In 


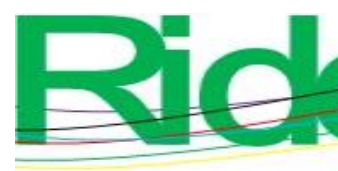

Revista Iberoamericana para la Investigación y el Desarrollo Educativo ISSN $2007-7467$

the verb-Framed languages, the verb lexicalizes the motion path in the same verb (la botella entró a la cueva flotando). This difference can be illustrated using English and Spanish languages, as seen below in table 2:

Table 2. Motion events in English and Spanish

\begin{tabular}{|l|l|}
\hline \multicolumn{1}{|c|}{ Spanish } & \multicolumn{1}{c|}{ English } \\
\hline El maestro salió del salón & The teacher got out of the classroom \\
\hline El maestro subió las escaleras & The teacher climbed up the stairs \\
\hline El maestro bajó las escaleras & The teacher climbed down the stairs \\
\hline El maestro regresó al salón & The teacher went back to the classroom \\
\hline
\end{tabular}

Source: Elaborated by the authors of this paper

As it is exemplified in table 2 above, the Spanish examples do require the use of a path verb to express the semantic meaning of movement and change of location. Summing up, in Spanish (a verb-framed language) the information about the path is encoded in the verb due to the existence of path verbs in Spanish. Those verbs lexicalize path and motion in the same verb (e.g. meter, sacar, entrar, bajar, etc.), whereas in English the path is encoded in the prepositions (satellite) and it is required a motion verb and a path preposition to express a manner of motion event in English. Nevertheless, English have path verbs such as enter, exit, ascent, etc. but those are not usually used to express motion. In other words, it is not common to use verbs borrowed from Latin to express motion in English. Aske (1989) stated that the reason is that it cannot get an exact match of a manner + motion along a path sentence in Spanish is because English has a richer path preposition (satellites) system as oppose to the Spanish path verb system. Also, Aske (1989) observed that in spite these facts, Spanish does have a rich set of locatives and path adverbs that just like English path prepositions/adverbs can take a ground complement, for example, dentro (de+), adentro; inside (of). These adverbials have a locative interpretation when used with non-path verb and can be interpreted as directional with path verbs. Nonetheless, manner + motion verbs like run or swim have a locative interpretation in Spanish. 


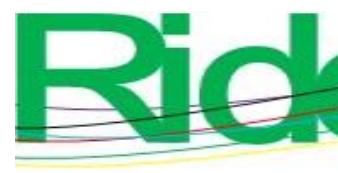

Revista Iberoamericana para la
Investigación y el Desarrollo Educativo
ISSN $2007-7467$

The learnability problem

Previous research (Inagaki, 2002, 2001) and Bautista-Maldonado (2011) has shown that languages that differ in the expression of events like English (John ran into the house) where it is used a manner-of-motion verb and a Prepositional Phrase (PP) its meaning indicate a directional reading. This is due to the conflation of the verb and the goal preposition.

This process of conflation causes learnability problems when learning a language that has not the same conflation of syntax-semantics in their cognitive repertoire. In another words, there is no match between satellite-framed languages and verb-framed languages when expressing an event using a manner of motion verb. For example, the Japanese language, which is classified as verb-framed language, similar as Spanish, has got the same learnability problem when learning English, specifically, the manner of motion verbs. In Japanese L2 learners of English tend to use the locative reading of John ran into the house due to the path is expressed in the verb. So when conflating syntax-semantics with mannerof-motion verbs we can get two readings depending on the Preposition (satellite) as the following examples illustrates:

\section{English Examples:}

The boat floated into the lake

(Directional reading in English)

The boat floated in the lake

(Locative reading in English)

The boat floated under the bridge

(Both locative and directional reading in English)

\section{Spanish Examples:}

El bote flotó en el lago

(Locative reading in Spanish)

El bote flotó bajo/debajo del puente

(Locative reading in Spanish)

So to express a directional reading Spanish needs, as suggested by Aske (1989) an adverbial or gerundive type construction such as El bote entró al lago flotando with the equivalent translation in English of "The boat entered to the lake by floating". 


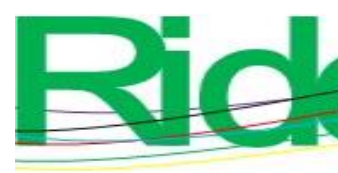

Revista Iberoamericana para la
Investigación y el Desarrollo Educativo
ISSN $2007-7467$

It is necessary to note that the Spanish directional "the boat entered to the lake by floating" is grammatically correct in English but it sounds unnatural, since the natural way to express directionality is with the construction "the boat floated into the lake". In this sense, when Spanish speakers are acquiring and or learning English, they tend to use the locative reading instead of the directional reading to express directionality or they tend to use the Spanish equivalent where a gerundive is required. In other words, L1 Spanish transfer the properties of the L1 into the L2. To test this, there were formulated the following research questions:

\section{Research Questions}

i. Do Spanish speakers initially assume that the realization of directed manner of motion constructions in English is the same as in Spanish? That is, will Spanish speakers initially assume that Peter danced into the room only has a locative interpretation.

ii. With proficiency, will Spanish learners of English establish that English manner of motion verbs with spatial PP complements can express manner of motion to goal? That is, if with more proficiency level of English Spanish speakers will map the directionality of the conflation pattern.

\section{Methodology}

Following a quantitative approach, the participants' general information is described here: 62 subjects participated in this research. All the participants were students attending a BA in English Language at a Public university in the southeast of Mexico. All the participants were administered a Placement Test in order to know their English proficiency level. Based on their obtained results, subjects were classified into three groups: 27 students with an Elementary level (Group 1), 15 at an intermediate level (Group 2), and 20 at an advanced level (Group 3). All of them were native speakers of Spanish, and none of them have lived in an English speaking country. The following table describe the information of the three groups. 


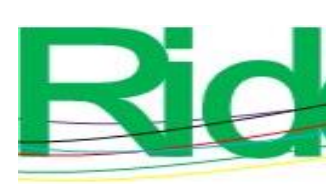

Revista Iberoamericana para la Investigación y el Desarrollo Educativo ISSN 2007 - 7467

Table 3. Participants' general information

\begin{tabular}{|c|c|c|c|}
\hline & $\begin{array}{c}\text { Group 1 } \\
\text { (n: 27) }\end{array}$ & $\begin{array}{c}\text { Group 2 } \\
\text { (n:15) }\end{array}$ & $\begin{array}{c}\text { Group 3 } \\
\text { (n:20) }\end{array}$ \\
\hline Gender & M: 7 & M: 6 & M: 3 \\
& F: 20 & F: 9 & F: 17 \\
Total: 27 & Total: 15 & 24 years old \\
\hline Age Mean & 20 years old & 20 years old & \\
\hline Time studying English (Mean) & 2.6 years & 3.7 years & 4.4 years \\
\hline
\end{tabular}

Source: Elaborated by the authors of this paper

\section{Instrument}

Data was collected using a Picture Matching Task (PMT) (Stringer, 2012). This instrument consisted of a series of pictures containing 11 test items. In each picture there were three sentences accompanied with a set of event denoting motion events. In each picture there was represented a motion verb and a path. Each sentence contained a different preposition but only one was correct depicting the picture shown. The narrative proposed by Stringer is as follows: a monkey sits in a tree-house about to eat his banana; a parrot swoops in, steals the banana, and flies off. The monkey chases the parrot, determined to retrieve his banana. Their chase takes the monkey through several different spatial environments. On each picture relevant to the analysis, the monkey follows a particular trajectory (e.g. 'down', 'under', 'over', etc.), varying with the obstacles he encounters, and he exhibits a particular manner of motion (e.g. he 'slides' down a tree-trunk, 'runs' under a bridge, 'jumps' over a rock etc.). The monkey follows the parrot into a cave, where they encounter a lion. After that, the lion chases them out of the cave, after which the parrot drops the banana and flies away. The monkey recovers it, then retraces his steps back home as fast as he can, going through all the motions a second time, before eating his banana in peace.

An example of one item is shown below in Figure 1: 


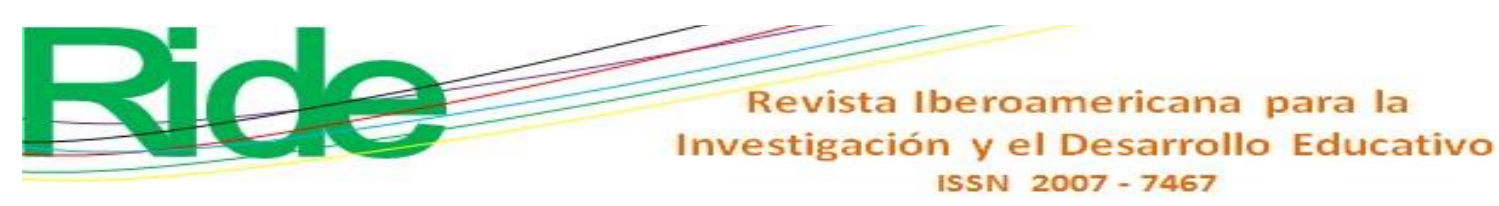

Figure 1. A sample of a test item (Stringer, 2012)

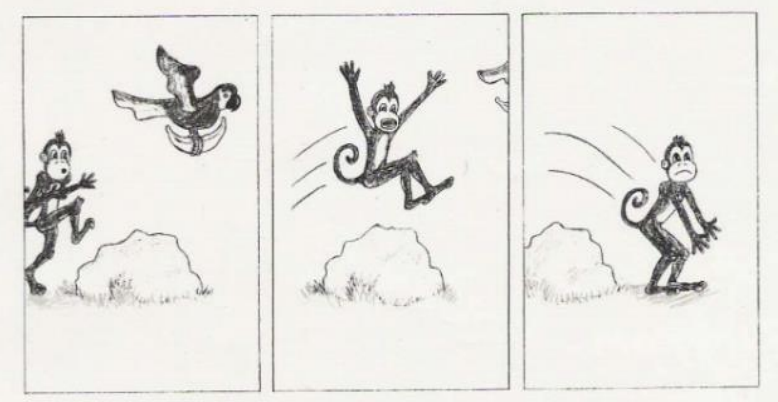

a. The monkey jumps by a rock while the parrot flies on top of it

b. The monkey jumps on top of a rock while the parrot flies up it

c. The monkey jumps over a rock while the parrot flies above it

Source: Stringer (2012) The monkey picture book

\section{Procedure}

Both the Placement test and the Picture Matching Task (PMT) were applied together. The Placement test took 30 minutes in total. The Placement Test contains 60 items in total. The presentation of the Placement test was a paper and pencil version. The Picture matching task was presented to participants using a projector in a whole class. Each slide was projected in a screen and the participants were given an answer sheet. The participants' task was to select the correct sentence, from the set of three choices, according to the action depicted by each picture. The slides were timed previously so they ran smoothly automatically one by one. It took 8 minutes to do the PMT. Both instruments were applied in a single session. After the administration of the tasks, the answers were coded and stored in an Excel file ready for statistical analysis. 


\section{Results}

Table 4. Results for the target construction are presented in the following table:

\begin{tabular}{|l|c|c|c|}
\hline Verb+ P & Group 1 (\%) & $\begin{array}{c}\text { Group 2 } \\
(\%)\end{array}$ & $\begin{array}{c}\text { Group 3 } \\
(\%)\end{array}$ \\
\hline Slides down & 78 & 80 & 85 \\
\hline Runs after & 63 & 33 & 70 \\
\hline Crawls through & 59 & 87 & 80 \\
\hline Jumps over & 33 & 60 & 70 \\
\hline Swim across & 96 & 80 & 85 \\
\hline Climbs up & 37 & 60 & 50 \\
\hline Rolls down & 78 & 53 & 55 \\
\hline Runs into & 74 & 73 & 75 \\
\hline Flies over & 63 & 33 & 65 \\
\hline Runs under & 59 & 33 & 70 \\
\hline Flies above & 37 & 60 & 70 \\
\hline
\end{tabular}

Source: Elaborated by the authors of this paper

At a glance, as it is showed in table 4 , it can be observed that there is no a pattern of development as it was expected. It was assumed that participants with higher level of English, participants would attain the native speaker use in L2 English. However, it seems that the participants with low level of English, group 1, are getting the right syntax and semantics, conflation pattern of a manner-of-motion verb with a Preposition of the constructions presented in the instrument. These results do show that Spanish speakers are getting the right syntax and semantics of the conflation of verbs and goal PP from the elementary levels. In other words, they are getting new parameters in L2 English, those parameters that are expressed differently in their L1, and this acquisition/learning might be due to the input they receive in class since the initial state of the $\mathrm{L} 2$.

The results are higher than 50\% in most of the items, except in climbs up, runs under and flies above with the group 1, and runs after, flies over, and runs under with the group number 2, and there is no evidence that the advanced group (group 3 ) is getting less than $50 \%$ of the correct items. It was expected an incremental percentage, in the combination of runs into, but it seems that all the three groups got almost the same \% (74\% for the group 1, 73\% for the group 2 and $75 \%$ for the group 3) so between groups there is not a significant difference in the mapping of runs into. What is really striking is the item swim across where the low level group got a higher percentage compared to the intermediate and advanced 


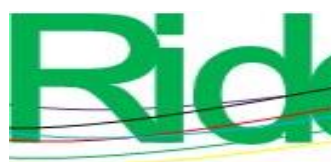

Revista Iberoamericana para la Investigación y el Desarrollo Educativo ISSN 2007 - 7467

participants, it was expected the opposite of the results shown here (swim across $96 \%$ for the group 1, 80\% for the group 2 and $85 \%$ for the group 3).

Table 5. Results of the non-target construction selected by the three groups

\begin{tabular}{|l|c|c|c|}
\hline Verb+ P & $\begin{array}{c}\text { Group 1 } \\
(\%)\end{array}$ & $\begin{array}{c}\text { Group 2 } \\
(\%)\end{array}$ & $\begin{array}{c}\text { Group 3 } \\
(\%)\end{array}$ \\
\hline *Slides over & 19 & 0 & 10 \\
\hline *Runs behind & 26 & 40 & 20 \\
\hline *Crawls inside & 37 & 13 & 15 \\
\hline *Jumps onto & 56 & 40 & 25 \\
\hline *Swim in & 4 & 13 & 45 \\
\hline *Climbs on & 59 & 13 & 45 \\
\hline *Rolls over & 15 & 40 & 35 \\
\hline *Runs inside & 22 & 20 & 25 \\
\hline *Flies in front of & 26 & 40 & 20 \\
\hline *Runs below & 30 & 40 & 20 \\
\hline *Flies up & 56 & 40 & 25 \\
\hline
\end{tabular}

Source: Elaborated by the authors of this paper

Table 5 shows that even with a more proficient level of English, participants of the group 3 are still using a wrong construction to express directionality with goal prepositions. It was expected that the group number 3 would have a minimum percentage compared to the other two groups with less proficiency. It was assumed that group 1 would have got a higher percentage of those incorrect, but the results do show the contrary. They are detecting that the goal preposition is not the right to express directionality depicted by the pictures presented in the instrument. The tendency expected here was that all participants of the group 1 will get a very high percentage of those incorrect constructions. Therefore, due to the less input received so far, the group 1 will have a higher choice of those incorrect and with more input these incorrect choices will disappear. The results of the three groups together were almost similar except in two items *jumps onto with percentages of 56, 40 and 25 and *flies up with percentages of 56, 40 and 25. Decrease in percentage was expected for all items but it seems that even at lower levels, the participants are getting the conflation pattern presented in table 4 and they are not selecting the wrong construction as illustrated in table 5. 


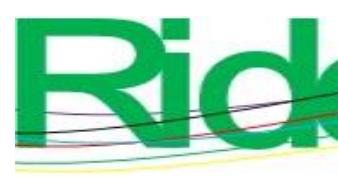

Revista Iberoamericana para la Investigación y el Desarrollo Educativo ISSN $2007-7467$

\section{Discussion}

Recalling that the research questions posted at the beginning were that Spanish speakers will initially assume that the conflation pattern of a manner-of-motion verb with a goal preposition will be given a locative reading instead of a directional reading and with more level of English they will map the correct event in L2 English. The results of this research do show the contrary in a sense that even at low elementary proficiency level of English; they are getting the directionality reading of the constructions tested in this research. Therefore, it seems that the proficiency level of English is not a factor to get the syntaxsemantics interface of the conflation proposed by Talmy. In general, Spanish speakers, not matter what proficiency level of English they have got, they recognize the directional reading of the sentences like John ran into the house, for example. This provide evidence of answering the research question number two. What is more, it seems that for Spanish speakers learning those semantic components is not a problem. Probably those results, as suggested by Inagaki, are the result of the "positive" and "robust" evidence the participants have in classroom environment. Alternatively, it is likely that presenting sequences of three pictures, as the instrument used was designed; it is more likely that the participants get the directionality instead of just showing a picture with arrows. To test if the instrument used is playing a role it is required more research with different instruments such as videoclips or another way to elicit intuitions from participants. In addition, the results do not show much evidence of the transfer process from constructions in the L1, Spanish, into the L2 English since in most of the items there were used ambiguous prepositions. So for future research There must be designed a similar instrument but with more items with into and onto where the directionality of the constructions will case difficulties for the Spanish speakers. 

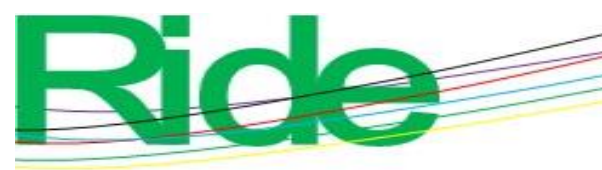

\section{Revista Iberoamericana para la Investigación y el Desarrollo Educativo} ISSN 2007 - 7467

\section{Conclusion}

The main objective of this research to test the effect that the L1 has into the L2 when acquiring a syntax-semantic interface in L2 English. There were formulated two assumptions at the beginning of the research and after that an instrument was applied in order to test those research questions. It was assumed that at the very elementary proficiency level of English the Spanish speakers, specially group 1, will have a locative reading due to the grammar of their L1, which was Spanish, to construction with the conflated pattern of motion in L2 English and with more proficiency, with group 2 and group 3, they will get the correct conflated pattern of the directionality meaning in English. However, the results do show that even at elementary levels of proficiency, the Spanish speakers are getting the right pattern in L2 English, contrary of what expected. It also seems that those results are suggesting that this parameter of variation between English and Spanish is not problematic for Spanish speakers, even though other authors such as Inagaki $(2001,2002)$ do suggest the contrary with Japanese speakers learning English. What is surprising here is probably the instrument administered to the participants, it seems that the instrument was easy to infer the motion due to the pictures presented and it is likely that if participants are taught with these kind of tasks they will get the conflation pattern in L2 English no matter what language they speak, even of the motion events are not present in their mother tongue.

The methodological implications for this research is that the motion pattern in L2 English is available both with a lot of input to L2 learners of English and it only requires the correct tasks to be practiced in classroom environments to trigger the acquisition or learning of that parameter of variation between Spanish and English. So, more practice in class will be advisable in order to get the conflation pattern of English since the elementary levels. 


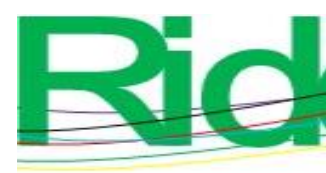

Revista Iberoamericana para la
Investigación y el Desarrollo Educativo
ISSN $2007-7467$

\section{Future lines of research}

It seems that the design of the instrument applied in this research was aimed to get the right use of the manner-of-motion event with the L1 Spanish speakers attending A BA in English language since elementary levels of proficiency, as it was showed by the positive results in the use of those constructions tested. So, for future research it is suggested to use a different task, or tasks, in order to get significant differences between groups and within groups. It is advisable to use video stimuli to show real movements of the Goal to the participants so they can react cognitively in more real time their intuitions of the events showed in the videos. And apart from this, It is required to apply the same instrument to a group of native speakers of English (control group) just to see if they are accepting the correct targeted item, if so , there will be more evidence to compare the native speakers of English with the native speakers of Spanish. What is more, it will be a good idea to test speakers with a different language than Spanish where the conflation of motion events are null, so it will be a good research testing if transfer properties from the L1 is playing a crucial role or if there is no transfer to what extent Universal Grammar is involved in the acquisition of the conflation patterns analyzed in this work. There is an open window to continue testing this phenomenon of syntax-semantics interface both in L1 and in L2, there must be done research using different tasks to elicit the intuitions of the participants and different age groups in order to stablish the age of acquisition of the pattern. All those opportunities are for future research. 


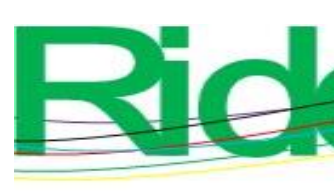

Revista Iberoamericana para la Investigación y el Desarrollo Educativo ISSN 2007-7467

\section{References}

Aske, J. (1989) Path predicates in English and Spanish: A closer look. In proceedings of the Annual Meeting of the Berkeley linguistics Society. Berkeley, Cal.: USA

Bautista-Maldonado, S. (2011) The acquisition of English manner-of-motion verbs and resultative constructions by native speakers of Spanish. Unpublished doctoral dissertation. University of Essex: UK

Folli, R. and Ramchand, G. (2005) Prepositions and results in Italian and English: an analysis from event decomposition. In H. Verkyul, H. van Hout, and H. de Swartz (eds.): Perspectives in Aspect, 1-20. Dordrecht: Kluwer Academic Publishers

Hawkins, R. (2019) How second languages are learned: An Introduction. Cambridge: Cambridge University Press

Inagaki, S. (2001) Motion verbs with goal PPs in the L2 acquisition of English and Japanese. Studies in Second Language Acquisition 23, (02), 153-170

Inagaki, S. (2002) Japanese learners' acquisition of English manner-of-motion verbs with locational/directional PPs. Second Language Research 18 (1), 3-27

Mateu, J. (2002) Learnability and the lexicon: Theories and second language acquisition research. Amsterdam: John Benjamins

Mateu, J. and Rigau, G. (2002) A minimalist account of conflation processes: Parametric variation at the lexicon-syntax interface. In Alexiadou, A. (ed.): Theoretical Approaches to Universals. Amsterdam: John Benjamins

Souza, R. (2012) Two languages in one mind and the online processing of causatives with manner-o fmotion verbs. ReVEL, special issue No. 6

Stringer, D. (2005) Children's structuring of motion events: syntactic universals and lexical variation. In Y. Ostu ( Ed.), Proceedings of the Sixth Tokio Conference in Psycholinguistics (pp.319-343) Tokio: Hitsuji Shobo

Stringer, D. (2012) Spatial Feature Assembly in First and Second Language Acquisition, Spatial Cognition \& Computation, 12: 252-274

Talmy, L. (1985) Lexicalization patterns: semantic structure in lexical forms. In Shopen, T. (ed.) Language typology and syntactic description, vol. 3 Grammatical categories and the lexicon. Cambridge: Cambridge University Press 

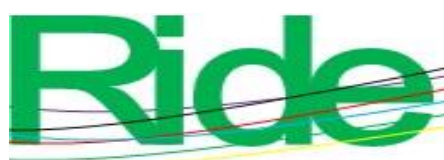

Revista Iberoamericana para la Investigación y el Desarrollo Educativo ISSN $2007-7467$

Talmy, L. (1991) Path to realization: A typology of event conflation. In proceedings of the $7^{\text {th }}$ Annual Meeting of the Berkeley Linguistic Society: General session and parasession on the grammar of event structure. 480-519. Berkeley, Cal.: USA

Talmy , L. (2000) Toward a cognitive semantics, Volume 2 : Typology and process in concept structuring. The MIT Press

Zubizarreta, M.L. and Oh, E. (2007) On the syntactic composition of manner and motion. The MIT Press 


\begin{tabular}{|c|c|}
\hline Rol de Contribución & Autor (es) \\
\hline Conceptualización & Salvador Bautista Maldonado \\
\hline Metodología & $\begin{array}{l}\text { Salvador Bautista Maldonado «principal» } \\
\text { Gina del Pilar Pacheco Balam «que apoya» } \\
\text { Rafael Ferrer Méndez «que apoya». }\end{array}$ \\
\hline Software & Rafael Ferrer Méndez \\
\hline Validación & $\begin{array}{l}\text { Gina del Pilar Pacheco Balam «igual» } \\
\text { Rafael Ferer Méndez «igual» }\end{array}$ \\
\hline Análisis Formal & $\begin{array}{l}\text { Salvador Bautista Maldonado «principall» } \\
\text { Rafael Ferrer Méndez «que apoya » }\end{array}$ \\
\hline Investigación & Salvador Bautista Maldonado \\
\hline Recursos & Gina del Pilar Pacheco Balam \\
\hline Curación de datos & $\begin{array}{l}\text { Rafael Ferrer Méndez «igual» } \\
\text { Gina del Pilar Pacheco Balam «igual» }\end{array}$ \\
\hline $\begin{array}{l}\text { Escritura - Preparación del } \\
\text { borrador original }\end{array}$ & Salvador Bautista Maldoado \\
\hline $\begin{array}{l}\text { Escritura - Revisión y } \\
\text { edición }\end{array}$ & $\begin{array}{l}\text { Gina del Pilar Pacheco Balam «igual» } \\
\text { Rafel Ferrer Méndez «igual» }\end{array}$ \\
\hline Visualización & Salvador Bautista Maldonado \\
\hline Supervisión & Salvador Bautista Maldonado \\
\hline Administración de Proyectos & Gina del Pilar Pacheco Balam \\
\hline Adquisición de fondos & Gina del Pilar Pacheco Balam \\
\hline
\end{tabular}

